\title{
The Role of Hindu Women in Increasing Family Income During the Covid-19 Pandemic
}

\author{
Luh Putu Ekawati ${ }^{1{ }^{*}}$ Ni Wayan Yulianita Dewi ${ }^{1}$ Made Aristia Prayudi ${ }^{1}$
}

\author{
Putu Ria Astria ${ }^{1}$ Made Denny Oktariyana ${ }^{1}$
}

\author{
${ }^{1}$ Department of Economics and Accounting, Universitas Pendidikan Ganesha, Singaraja, Indonesia \\ *Corresponding author. Email:Iuhputuekawati18@gmail.com
}

\begin{abstract}
Economic activity is an integral part of our lives. There is nothing wrong with Hindus seeking wealth. However, Arthasastra said that in seeking wealth Hindus should hold on to virtue, it is very justifiable that we seek money to support the household as long as it is in the right way. The Corona virus outbreak has an impact on the economy and other sectors. The decline in economic activity also affects women. Decreased business activity, layoffs and double burden on the family. This pandemic is most felt by women, especially those from pre-prosperous families. This vulnerability is not caused by weak women, but because of the patriarchal values that are still embraced by society. The patriarchal system states that women are inferior to men. Women who were not working before the pandemic are now in the workforce to help support the family's economic needs. Conditions that require women to work in order to increase their husband's income also occur in Singaraja. The location was chosen purposively as a research location, taking into account that in Singaraja there are various types of work in the non-formal sector and the role of the head of the family in providing for the family. household cannot fully be done without the help of the wife. In this study, the gender concept of Julia Cleves Mosse is used as an analytical tool. Mosse defines gender is not a biological thing but a cultural gift. Gender provides a set of roles between women and men in society. Gender roles change over time and differ from one culture to another. This happens because of an economic contraction that requires women to act as breadwinners. in increasing family income in the city of Singaraja during the Covid-19 pandemic. This study uses a qualitative method that uses the theoretical basis of phenomenological studies. Data collection techniques, interviews, observation, documentation, and literature study. The results of this study are Hindu women today have a dual role, namely as housewives who carry out work at home and work outside the home to increase husband's income in fulfilling household life. Hindu women in the city of Singaraja during the Covid-19 pandemic have the same opportunities as men to earn a living for the needs of their families. With the advancement of technology and its use, it can have a positive impact on daily life, both the role of women who are natural and become women with careers. To maintain the integrity of the household, Hindu women carry out their roles in accordance with their swadharma as a woman, namely applying the values of loyalty to their families that can be realized, namely by serving their husbands well, paying attention, educating and guiding their children, organizing religious activities, and play an active role in increasing family income.
\end{abstract}

Keywords: Women in Hindu literature, Gender, The Role of Hindu Women in Increasing Income.

\section{INTRODUCTION}

The elaborate ritual traditions that require a lot of money and time, as well as other customs that are built on myopic views have become a heavy burden on the lives of Hindus in Bali, especially women [1]. Women in Hinduism are the organizers of religious ceremonies both in the household and in the community. Economic activity is an integral part of our lives. There is nothing wrong with Hindus seeking wealth. However, Arthasastra said that in seeking wealth Hindus should hold on to virtue, it is very justifiable that we seek money to support the household as long as it is in the right way [2]. Women in Hindu households bring peace 
and joy to their families. Hindu women always compete to be the ideal companion of their husbands (in Hinduism it is called Sati), burdened with moral responsibilities to be able to take care of, care for, and educate mankind. With this, women are mighty creatures created by God who have the task of raising children, husbands and families who adhere to Hinduism by practicing the teachings of goodness [3].

The family in Hinduism is an important element in carrying out Yadnya and devotion to Idha Sang Hyang Widhi Wasa. Family can be interpreted as a relationship or bond of devotion between husband, wife and children. The basis of family ties is "devotion" not sacrifice. All family members, namely husband, wife, and children must be fully aware that what is done in the family is solely the mandate of Idha Sang Hyang Widhi Wasa [4]. So that everything is done based on pure sincerity.

The Corona virus outbreak has an impact on the economy and other sectors. Economic growth eroded to minus 5 (five) percent in the second quarter of 2020. The decline in economic activity also affected women. Decreased business activities, layoffs and double burdens in the family [5]. This pandemic is most felt by women, especially those from pre-prosperous families. This vulnerability is not caused by weak women, but because of the patriarchal values that are still embraced by society. The patriarchal system states that women are inferior to men.

During the Covid-19 pandemic, women became family managers, helping the family economy to accompanying children to study at home. A mother will naturally do anything for the safety of her family. Women who were not working before the pandemic are now in the workforce to help support the family's economic needs. Finance Minister Sri Mulyani said Covid-19 had a very large impact on women. All sectors, both formal and non-formal, especially micro, small and medium enterprises (MSMEs) where the majority of the workers are $93 \%$ women [6]. Therefore, to survive to meet the needs of the family in the conditions of the COVID-19 pandemic is not easy. It takes vigilance in strategy to survive. Humans need primary needs such as clothing, food, and shelter. If the work is hampered it will cause prosperity in his life. Economic factors in a society are very important because they support the life of each individual [7].

Conditions that require women to work in order to increase their husband's income also occur in Singaraja. The location was chosen purposively as a research location, taking into account that in Singaraja there are various types of work in the non-formal sector and the role of the head of the family in providing for the family. household cannot fully be done without the help of the wife. Most of the wives in this case are Hindu women in addition to carrying out their roles as wives, preparing religious ceremonies, also taking care of their children, working in the non-formal sector, such as selling in the market, housemaids, daily laborers, construction workers, washers, and others. etc.

In this study, the gender concept of Julia Cleves Mosse is used as an analytical tool. Mosse defines gender is not a biological thing but a cultural gift. Gender provides a set of roles between women and men in society. In more detail, the set of roles includes appearance, dress, attitude, personality, work inside and outside the household, sexuality, family responsibilities and so on. Gender roles change over time and differ from one culture to another. This happens because of an economic contraction that requires women to act as breadwinners. However, the status of women in the family cannot be called "Head of the Household". Women who act as the main breadwinners, remain in the status of "wife" and "mother" which is characterized by domestic activities and taking care of children. Whereas a man or husband who cannot fulfill his obligations to earn a living, he still has the status of "Head of the Household" [8].

\section{METHOD}

This study uses a qualitative method that uses the theoretical basis of phenomenological studies. In this qualitative research reveals the phenomena that occur in a life in the household. The research was conducted in Singaraja. All informants are Hindu women who work in the non-formal sector, and the role of the head of the family in providing for the household cannot be fully done without the help of the wife. Data collection techniques carried out Interview, observation, documentation, and literature study.

\section{RESULTS \& DISCUSSION}

\subsection{The Role of Hindu Women in Singaraja}

Hinduism is the eternal truth (Sanatana Dharma) which in its teachings comes from the Vedas. Hindu religious scriptures highly uphold the dignity of women. Women in Indian and Old Javanese literatures have an important role in their participation to build prosperity and peace in this life for the better. In the book Manawa Dharmasastra III: 56 explains that when women are not respected, then all yadnya are not rewarded. Women should play an active role in the practices that are in accordance with bhakti, karma, jnana, and yoga. So that the goal of Hindu life is achieved, namely Catur Purusa Artha (dharma, artha, kama, and moksa) [9].

The discussion in the results of this study only discusses the role of Hindu women in the family and the role of Hindu women in increasing family income during the Covid-19 pandemic 


\subsubsection{The Role of Hindu Women in the Family}

A happy and prosperous family (sukhinah) is the goal of Vivaha samkara in Hindu terminology. A sukhinah family is a family formed based on a legal marriage, because the forerunner of a basic family is a marriage between a woman and a man so as to produce offspring, able to meet the needs of a decent spiritual and material life, fear God Almighty, have a harmonious relationship, harmonious and balanced between members and between families with society and the environment [10]. Marriage is a sacred event and an obligation for Hindus. In accordance with the teachings of the Vedas in the book Manawa Dharma Sastra III 60 as follows "Samtusto bharyaya bharta tathaiva ca, Yasminnewa kule nityam kalyanam tatra wai dhruwam". This means that in a family where the husband is happy with his wife and so is the wife for her husband, happiness must be eternal. Therefore, every husband and other family members must be able to participate in creating so that women always live with feelings of pleasure, always have a radiant face. Only under such conditions will the family be given peace, shade, and ultimately true happiness, as stated in the following Manawa Dharma Sastra verse: Striya tu rocamanayam, Sarwam, tadrocate kulam, Tasyam twarocamanayam, Sarwamewa na rokate (MDS, III, 62) meaning: If the wife always has a radiant face, the whole house will look radiant, but if she does not have such a face, everything will look gloomy. Jamayo yani gehani, Capantya patri Pujitah, Tani krtyahatanewa, Winacyanri samantarah (MDS, III, 58) means: A house where women are not properly respected, Says cursed words, The family will be completely destroyed, As if destroyed by supernatural forces [9]. The elements of a sukhinah (happy and prosperous) family according to Hinduism contained in the Vedas are (1) love, (2) the joy of not bearing Papa and Sin, and (3) satisfaction [10].

\subsubsection{The Role of Hindu Women in Increasing Family Income During the Covid-19 Pandemic}

In the household, women act as wives and housewives who have heavy obligations and responsibilities. Housewives have a more respectable position than husbands. As a wife, her position is equal to that of her husband. Hindu women in their efforts to maintain family resilience is by improving the family economy. Today's Hindu women have a dual role, namely as housewives who carry out work at home and work outside the home to supplement their husband's income in fulfilling their household life.

Hindu women in the city of Singaraja during the Covid-19 pandemic have the same opportunities as men to earn a living for the needs of their families. With the advancement of technology and its use, it can have a positive impact on daily life, both the role of women who are natural and become women with careers. To maintain the integrity of the household, Hindu women carry out their roles in accordance with their swadharma as a woman, namely applying the values of loyalty to their families that can be realized, namely by serving their husbands well, paying attention, educating and guiding their children, organizing religious activities, and play an active role in increasing family income.

\subsection{Constraints Faced by Hindu Women in Increasing Family Income in Singaraja During the Covid-19 Pandemic}

\subsubsection{Women's double burden}

In the current era, the work between men and women has experienced a balance. Women do not only work in the domestic sector, in the public sector there are also many women [11]. The double burden of women can be seen in the imbalance of prevailing social relations. Women do household chores such as serving their husbands and children, cleaning everything in the house, and cooking for the family's food needs. In addition, women are also still working to improve the family economy. Hindu women who work because of the household economy demand that they participate in meeting their needs.

\subsubsection{Economic Factor}

Uncertain income makes Hindu women feel a heavy burden in managing the family economy. The instability of economic conditions due to the Covid-19 pandemic has resulted in concurrently, namely a contraction of income and limited space for consumption. Revenue contractions occurred due to layoffs (PHK), salary reductions, and decreased operating profits. Meanwhile, the limitation of consumption space is due to the limitation of people's mobility [12]. The importance of financial management by Hindu women and the application of household accounting in Hindus, especially during the covid-19 pandemic, aims to increase the standard of living, the standard of living in question is so that the family is always harmonious, happy to avoid financial problems [1].

\subsubsection{Social and Cultural Factors}

Hindu women as organizers of religious ceremonies both in the household and in the community. The Manawa Dharmasastra explains that religious ceremonies are the happiness of the household, and the ancestral paradise supported by the wife. The wife has a role as a mother and as a religious executor (yadnya) which includes the implementation of the Panca Yadnya consisting of Dewa Yadnya, Pitra Yadnya, Rsi Yadnya, Manusa Yadnya and Bhuta Yadnya. As a wife should be 
used as an example because as a reliable organizer of religious ceremonies in the household. Starting from preparing ceremonial facilities to giving offerings at every Hindu holy holiday celebration. In this case, the contribution of a wife is far more than a man who only helps, no matter how busy a mother is, she takes the time to come to the temple to carry out meayah-father activities. Ngayah is a Balinese social obligation that is carried out in mutual cooperation with a sincere heart, both in banjars and in temples or holy places, without expecting anything in return or material things. By doing ngayah, they have also fulfilled their social and religious obligations of Hinduism.

\section{CONCLUSION}

In accordance with the results of research and discussion on the role of Hindu women in increasing income in the city of Singaraja during the Covid-19 pandemic, it can be concluded that a happy and prosperous family (sukhinah) is the goal of Vivaha samkara in Hindu terminology. In the following Manawa Dharma Sastra verse: Striya tu rocamanayam, Sarwam, tadrocate kulam, Tasyam twarocamanayam, Sarwamewa na rokate (MDS, III, 62) it means: If the wife always has a radiant face, the whole house will look radiant, but if she does not with such a face, everything will look gloomy. Jamayo yani gehani, Capantya patri Pujitah, Tani krtyahatanewa, Winacyanri samantarah (MDS, III, 58) means: A house where women are not properly respected, speaks cursed words, The family will be completely destroyed, As if destroyed by supernatural forces.

Also, Hindu women in the city of Singaraja as informants in this study are very active in financial management in their households. During the Covid-19 pandemic, women became family financial managers, helping the family economy to accompanying children to study at home. A mother will naturally do anything for the safety of her family. In addition, the double burden experienced by Hindu women has an unyielding spirit, even though in their daily life they can feel tired. This situation makes the psychological condition of women also affected because they think about all kinds of activities. Women work more than men. The obstacles faced by Hindu women in increasing family income in the city of Singaraja during the Covid-19 pandemic were influenced by several factors, namely, double burden, economy and socio-culture. Women who were not working before the pandemic are now in the workforce to help support the family's economic needs.

In accordance with the results of research and discussion on the role of Hindu women in increasing income in the city of Singaraja during the Covid-19 pandemic, it is better if Hindu women's efforts in overcoming income problems during the pandemic are to keep working hard and trying to manage between income and expenses so that the existence of the household can be maintained. The level of family life and the manner in which income is earned and used should receive attention. On the other hand, the local government should pay more attention to the condition of women to be more empowered. For example, in domestic and public affairs to be more equal, between men and women are equally balanced in carrying out daily activities.

\section{REFERENCES}

[1] Putu Ekawati, Peran Perempuan Hindu Dalam Pengelolaan Keuangan Dan Penerapan Akuntansi Menuju Keluarga Hindu Yang Sukhinah Di Masa Pandemi Covid-19. 2021.

[2] N. Sumantra, "Cinta Damai Sumantra," https://sumantre.blogspot.com/, 2010. .

[3] P. S. Junianti and I. M. W. Kusuma, "Perempuan Hindu di Era Globalisasi," Sphatika J. Teol., vol. 10, no. 1, p. 99, 2019, doi: 10.25078/sp.v10i1.1570.

[4] I. Univ, "Kedudukan Perempuan dalam Keluarga Hindu",."

[5] Tempo, "Peran Perempuan Dimasa Pandemi," 26 April, 2021. .

[6] A. Armi, S. Soeaidy, and A. Hayat, "Dampak Sosial Ekonomi Kebijakan Relokasi Pasar (Studi Kasus Relokasi Pasar Dinoyo Malang)," J. Adm. Publik, 2016.

[7] A. Biroli, "Beban Ganda Perempuan dalam Mendukung Perekonomian Keluarga di Masa Pandemi Covid-19 Alfan Biroli * dan Ekna Satriyati Latar Belakang Kemunculan covid-19 disinyalir pertama kali ditemukan di Wuhan Cina pada Dibutuhkan kesiapsiagaan dalam strategi untuk be," vol. 1, pp. 71-80, 2021.

[8] E. K. Sari and B. N. Fikri Zufar, "Perempuan Pencari Nafkah Selama Pandemi Covid-19," AlMada J. Agama, Sos. dan Budaya, vol. 4, no. 1, pp. 13-29, 2021, doi: 10.31538/almada.v4i1.1106.

[9] I. B. Triguna, "Keluarga Bahagia Dan Sejahtera Dalam Perspektif Hindu," https://www.yudhatriguna.com/, p. 1, 2019.

[10] A. Sumartini, "Keluarga Sukinah Hindu," https://ayusumartini/blogspot.com/2015, 2015. .

[11] I. Chairani, "Dampak pandemi covid-19 dalam perspektif gender di indonesia," J. Kependud. Indones., vol. Edisi Khus, no. Juli, pp. 39-42, 2020, doi: https://doi.org/10.14203/jki.v0i0.571.

[12] A. Nugroho, "Survei Dampak Pandemi COVID-19 terhadap Ekonomi Rumah Tangga Indonesia," LIPI Indonesia Institute, p. 2, 2020. 